\title{
THE EFFECT OF CURCUMA XANTHORRHIZA - ETHANOL EXTRACT TO BIOFILM FORMATION OF STREPTOCOCCUS MUTANS AND AGGREGATIBACTER ACTINOMYCETEMCOMITANS (DENTAL BIOFILM RESEARCH: IN VITRO STUDY)
}

\author{
FIDHIANISSA, HEDIJANTI JOENOES, ARIADNA A. DJAIS*
}

Department of Oral Biology, Faculty of Dentistry, Universitas Indonesia, Jakarta, Indonesia. Email: ariedjais26@gmail.com Received: 21 April 2017, Revised and Accepted: 13 July 2017

ABSTRACT

Objective: This in vitro study aimed to analyze the mass ratio of single- and dual-species Streptococcus mutans and Aggregatibacter actinomycetemcomitans biofilm after exposure to Curcuma xanthorrhiza ethanol extract (Xan).

Methods: A bacterial suspension in brain heart infusion medium, enriched with $0.2 \%$ sucrose, was exposed to the Xan, incubated for 18 hrs, and analyzed using a crystal violet assay.

Results: This research concluded that the minimum inhibitory concentration of ethanol-temulawak extract against S. mutans was 5\%, while the minimum bactericidal concentration was $15 \%$.

Conclusions: Xan prevented biofilm formation of single-species $S$. mutans and dual-species $S$. mutans and A. actinomycetemcomitans more effectively than it did single-species A. actinomycetemcomitans.

Keywords: Biofilm formation, Single-species biofilm, Dual-species biofilm, Streptococcus mutans, Aggregatibacter actinomycetemcomitans, Curcuma xanthorrhiza ethanol extract, Crystal violet assay.

(C) 2017 The Authors. Published by Innovare Academic Sciences PvtLtd. This is an open access article under the CC BY license (http://creativecommons. org/licenses/by/4. 0/) DOI: http://dx.doi.org/10.22159/ijap.2017.v9s1.14_16

\section{INTRODUCTION}

Dental and oral health problems, particularly caries and periodontal disease, are common in Indonesia. The Indonesia national health survey in 2013 results show prevalence at about $25.9 \%$ nationally, with 14 provinces having higher prevalence than that [1,2]. Dental caries and periodontal disease are caused by oral bacteria in biofilm form. Streptococcus mutans is the main etiological agent of dental caries, working as an early colonizer to start the formation of dental plaque [3,4]. The Aggregatibacter actinomycetemcomitans bacterium interacts with other bacteria in a biofilm to produce virulence factors and thus cause periodontal disease. Biofilm itself is a structure made up of an extracellular polymer matrix embedded with same- or mixedspecies bacteria that form a community and adhere to the tooth surface. It is the main causative agent of caries and periodontal disease, as it is resistant to antimicrobial agents. Great importance is therefore given to finding a new antimicrobial agent to control biofilm $[2,5]$.

The Indonesian government is currently developing the use of medicinal plants. The Indonesian Food and Drug Administration (BPOM) has highlighted nine as superior, one of them being temulawak, Curcuma xanthorrhiza (Xan). This plant, also called Java ginger and Javanese turmeric, contains Xan, an agent with a considerable antibacterial effect that can be used as an alternative herbal antibacterial agent. Its extract form is expected to maximize the effect of Xan and other active agents contained in the plant [6,7]. Because $S$. mutans and A. actinomycetemcomitans in the biofilm are primary bacterial agents of dental caries and periodontal disease, an examination of the effect of temulawak extract on biofilm formation would be a useful preventive approach. This study aimed to evaluate the effect of temulawak extract on single- and dual-species $S$. mutans and A. actinomycetemcomitans biofilm formation.

\section{METHODS}

The raw material for this experimental laboratory study was ethanoltemulawak extract obtained from BALITRO, Bogor. The extract was centrifuged (at $3000 \mathrm{rpm}$ for 20 minutes at $4^{\circ} \mathrm{C}$ ) and the supernatant layer collected. The supernatant was diluted using 10\% dimethyl sulfoxide to produce several final concentrations $(0.5 \% ; 1 \%$; $5 \% ; 10 \%$; $15 \% ; 20 \%$; and $25 \%$ ), determined by volume comparison formula. The bacterial culture was started by isolating $10 \mu \mathrm{l}$ of each species. The bacteria were inoculated into brain heart infusion (BHI) medium and incubated in an anaerobic chamber for $2 \times 24$ hrs for S. mutans and $3 \times 24$ hrs for A. actinomycetemcomitans. From each inoculation set, one colony was collected to make aliquots. To decide the amount of bacteria to be tested, the aliquots were diluted in steps from 10-1 to $10-8$, and then, inoculated into BHI medium. The bacterial colony count identified the 10-5suspension as the best for the experiment, as the colony numbers were high enough to give significant results while being low enough for accurate counting. To conduct minimum inhibitory concentration (MIC) and minimum bactericidal concentration (MBC) assays, $100 \mu$ l volumes of the 10-5 bacterial suspension were transferred into each well of a 96-wellplate before $100 \mu \mathrm{l}$ of the different concentrations of ethanoltemulawak extract were added. The 96-well plate was then incubated in an anaerobic chamber for 48 hours. The MIC and MBC values were then calculated, using a formula modified from Quave, with $\geq 90 \%$ as MIC and $\geq 99 \%$ as $\mathrm{MBC}[8,9]$.

A BHI broth medium, $0.2 \%$ sucrose enriched, was prepared before the dilution of the bacteria. The bacteria were then diluted in the way described above, to make a 10-5 bacterial suspension. For A. actinomycetemcomitans, $1 \mathrm{ml}$ of vitamin $\mathrm{K}$ was added to the $0.2 \%$ sucrose-enriched BHI broth. For each of three groups (treatment group, negative control group, and positive control group), $100 \mu \mathrm{l}$ of 10-5 bacterial suspension in $0.2 \%$ sucrose-enriched BHI broth were put in each well. Each group was exposed to $100 \mu \mathrm{l}$ of ethanoltemulawak extract or Xan in each of the various concentrations. The positive control group was exposed to $100 \mu \mathrm{l} 0.2 \%$ chlorhexidine (CHX), the negative control group received $100 \mu \mathrm{l}$ of $0.2 \%$ sucroseenriched BHI broth, and the blank group contained $100 \mu \mathrm{l}$ of $0.2 \%$ sucrose-enriched BHI broth and $100 \mu \mathrm{l}$ of the tested material. For the dual-species bacterial suspension biofilm, $50 \mu \mathrm{l}$ of $S$. mutans and $50 \mu \mathrm{l}$ 
of $A$. actinomycetemcomitans were added. This procedure used triplo. Afterward, the 96 -well plates were incubated for 18 hours at $37^{\circ} \mathrm{C}$ in an anaerobic chamber.

After incubation, the liquids were aspirated and rinsed once with phosphate buffered saline (PBS) then fixed for 10 minutes before coloring with $0.5 \%$ crystal violet solution. The $0.5 \%$ crystal violet solution was prepared by mixing $250 \mu \mathrm{l}$ of $100 \%$ crystal violet with $49.75 \mathrm{ml}$ of aquadest distilled water. Each well received $200 \mu \mathrm{l}$ of crystal violet solution before a further incubation for 15 minutes at $37^{\circ} \mathrm{C}$. The crystal violet solution was then aspirated and the 96-well plate rinsed twice with sterile aquadest. Next, $200 \mu \mathrm{l}$ of $96 \%$ ethanol were added to each well to dissolve the crystal violet before a third incubation, again for 15 minutes at $37^{\circ} \mathrm{C}$. After the incubation, the optical density value was read with a microplate reader at a wavelength of $490 \mathrm{~nm}$. Biofilm inhibition was determined if the value reached $50 \%$ or more [8]. Data analysis was performed using ANOVA for the differentiation test, followed by the Pearson correlation test; linear regression was used to analyze the relationship between independent variables (concentration of ethanol-temulawak extract) and dependent variables (biofilm formation inhibition value).

\section{RESULTS}

Before the biofilm model test was performed, a research had been conducted to determine the MIC and MBC of ethanol-temulawak extract on $S$. mutans and A. actinomycetemcomitans. The research reported that the MIC of ethanol-temulawak extract on $S$. mutans was $5 \%$, MBC $15 \%$. The MIC and MBC of ethanol-temulawak extract on A. actinomycetemcomitans were not determined because no inhibition percentage value on that species reached $90 \%$ (Table 1 ).

Table 2 shows that the inhibition values of ethanol-temulawak extract against formation of single-species $S$. mutans and dualspecies $S$. mutans/A. actinomycetemcomitans biofilms were over $50 \%$ in all concentrations, but did not reach $50 \%$ against formation of singlespecies A. actinomycetemcomitans biofilm for any concentration. The

Table 1: Exposure of S. mutans and A. actinomycetemcomitansto ethanol-temulawak extract

\begin{tabular}{lll}
\hline Group & $\begin{array}{l}\text { Inhibition }(\%) \pm S D \\
\text { S. mutans }\end{array}$ & $\begin{array}{l}\text { Inhibition (\%) } \pm \text { SD } \\
\text { A. actinomycetemcomitans }\end{array}$ \\
\hline Negative control & 0 & 0 \\
Positive control & $100.19 \pm 0.94$ & $100.28 \pm 0.26$ \\
0.5 & $85.85 \pm 1.20$ & $83.44 \pm 9.20$ \\
1 & $88.78 \pm 1.30$ & $81.86 \pm 6.27$ \\
5 & $91.14 \pm 1.42(\mathrm{KHM})$ & $82.69 \pm 8.84$ \\
10 & $95.16 \pm 2.59$ & $88.18 \pm 2.93$ \\
15 & $100.37 \pm 0.83(\mathrm{KBM})$ & $82.59 \pm 7.42$ \\
20 & $100.04 \pm 0.96$ & $83.90 \pm 3.89$ \\
25 & $101.62 \pm 1.96$ & $83.60 \pm 6.90$ \\
$10 \%$ DMSO & $16.51 \pm 2.14$ & $13.17 \pm 1.16$ \\
solution & & \\
\hline
\end{tabular}

DMSO: Dimethyl sulfoxide, S. mutans: Streptococcus mutans
ANOVA test concluded that there was a significant difference $(\mathrm{p}<0.05)$ between negative and positive control in all biofilm formation groups, at all concentrations. Fig. 1 demonstrates a tendency for higher concentrations of ethanol-temulawak extract to give higher inhibition values in all groups. This result was confirmed by the correlation and regression tests, which showed a strong positive correlation between inhibition value and concentration of ethanol-temulawak extract in all groups.

\section{DISCUSSION}

This research has revealed that ethanol-temulawak extract has an MIC of $5 \%$ and an MBC of $15 \%$ against $S$. mutans, but has no measurable MIC or MBC against A. actinomycetemcomitans. This is due to the different cell wall linings of the two bacteria. S. mutans is Gram-positive, with a simple cell wall lining, while A. actinomycetemcomitans is Gram-negative and has a more complex lining. As it has no outer layer, antimicrobial agents can permeate the $S$. mutans cell wall and cause biosynthesis disturbance. The hydroxyl group in the Xan contained in ethanoltemulawak extract contributes to antimicrobial activity by inducing cell wall protein denaturation; the protein of the cell leaks out and causes cell death $[10,4]$. In the Gram-negative A. actinomycetemcomitans; however, the outer layer consists of lipopolysaccharide, lipoprotein, and periplasm bound to peptidoglycan. The lipopolysaccharide functions as a defense system with the peptidoglycan and rejects foreign substances. Lipoproteinin the outer membrane of Gram-negative bacteria contains porin, ahydrophilic protein, and it is very possible that it makes the cell impermeable to the hydrophobic ethanol-temulawak extract [10].

The biofilm inhibition value for the positive control group is $50 \%>$ value determined for the negative control group. This study found that ethanol-temulawak extract inhibited $S$. mutans biofilm formation in all concentrations, and that increased concentration is linearly correlated with increased inhibition value. The correlation test gives a coefficient of correlation of 0.801 , indicating a strong, positive relationship between concentration and inhibition value of ethanol-temulawak extract against formation of single-species $S$. mutans biofilm. It is now proved that ethanol-temulawak extract can prevent $S$. mutans biofilm formation, but not as effectively as CHX. The ethanol-temulawak extract

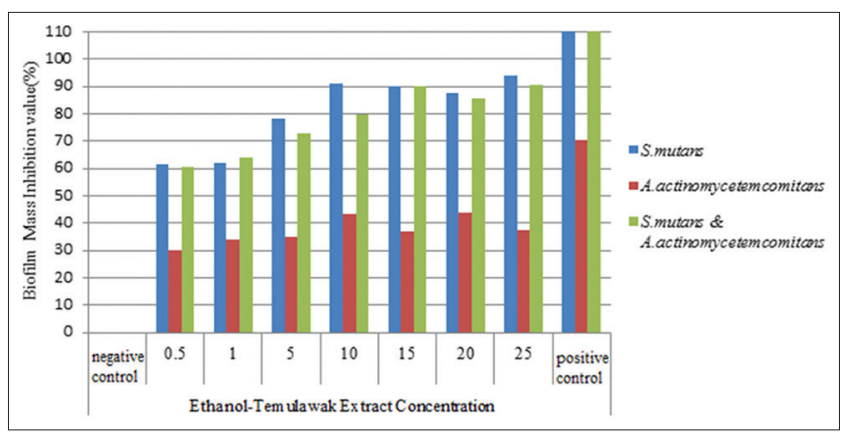

Fig. 1: The Effect of ethanol-temulawak extract on single- and dual-species biofilm formation

Table 2: The Effect of Ethanol-temulawak extract on single- and dual-species biofilm formation

\begin{tabular}{|c|c|c|c|}
\hline Group & $\begin{array}{l}\text { Inhibition }(\%) \pm \text { SD } \\
\text { single-species } S . \text { mutans }\end{array}$ & $\begin{array}{l}\text { Inhibition }(\%) \pm \text { SD single-species } \\
\text { A. actinomycetemcomitans }\end{array}$ & $\begin{array}{l}\text { Inhibition }(\%) \pm \text { SD dual-species } S . \text { mutans and } \\
\text { A. actinomycetemcomitans }\end{array}$ \\
\hline Negative control & 0.00 & 0.00 & 0.00 \\
\hline Positive control & $110.53 \pm 11.28$ & $70.23 \pm 0.88$ & $110.85 \pm 3.10$ \\
\hline $0.5 \%$ & $61.50 \pm 8.18$ & $29.92 \pm 1.69$ & $60.61 \pm 1.84$ \\
\hline $1 \%$ & $61.88 \pm 6.83$ & $33.86 \pm 0.91$ & $64.03 \pm 3.13$ \\
\hline $5 \%$ & $78.37 \pm 11.77$ & $34.97 \pm 0.84$ & $72.78 \pm 3.49$ \\
\hline $10 \%$ & $90.91 \pm 1.50$ & $43.25 \pm 4.65$ & $79.82 \pm 1.84$ \\
\hline $20 \%$ & $87.81 \pm 2.86$ & $43.92 \pm 2.85$ & $85.70 \pm 1.07$ \\
\hline $25 \%$ & $93.81 \pm 0.49$ & $37.54 \pm 0.50$ & $90.54 \pm 1.22$ \\
\hline
\end{tabular}


works by disrupting cell wall integrity, causing lysis with disruption of the cell wall and membrane, and thus, destroying the ability of S. mutans to adhere and form a biofilm [11,4]. The effect of ethanoltemulawak extract against $A$. actinomycetemcomitans biofilm formation was determined in the same way as for $S$. mutans. The study showed that ethanol-temulawak extract could not prevent single-species A. actinomycetemcomitans biofilm formation. This resistance to ethanoltemulawak extract is probably caused by the inability of the ethanoltemulawak extract to permeate the cell wall, so that biofilm formation continues [10]. However, the correlation test gave a coefficient of correlation of 0.594 , meaning that there was a relationship between the concentration and inhibition value of ethanol-temulawak extract against single-species $A$. actinomycetemcomitans biofilm formation. It was presumed that the ability of ethanol-temulawak extract to inhibit A. actinomycetemcomitans biofilm formation is over $25 \%$, but no inhibition value could be determined.

In the dual-species biofilm study, ethanol-temulawak extract could prevent the formation of dual-species biofilm in every concentration. The correlation test gave a coefficient of correlation of 0.920 , proving a strong relationship between increased concentration and increased inhibition value. This is probably caused by several interactions between the two bacteria. As a metabolism by product, $S$. mutans produces lactic acid, an important energy source for A. actinomycetemcomitans. S. mutans was exposed to ethanol-temulawak extract before receiving sucrose, so was already undergoing lysis, no longer producing lactic acid, and thus, diminishing the ability of A. actinomycetemcomitans to grow. In turn, the growth of $S$. mutans is probably disturbed by the actinobacilin produced by A. actinomycetemcomitans. Thus, in the dualspecies biofilm, only A. actinomycetemcomitans can survive to form a biofilm; the biofilm formation was probably reduced because the gross number of A. actinomycetemcomitans originally introduced was only half the number used in the single-species experiments [12-14].

\section{CONCLUSION}

This research concluded that the MIC of ethanol-temulawak extract against $S$. mutans was $5 \%$, while the MBC was $15 \%$. The MIC and MIB of ethanol-temulawak extract against $A$. actinomycetemcomitans could not be determined. In vitro, ethanol-temulawak extract could prevent the formation of a single-species biofilm of $S$. mutans and a dual-species biofilm of S. mutans and A. actinomycetemcomitans. However, ethanoltemulawak extract could not prevent the formation of a single-species biofilm of A. actinomycetemcomitans. The recommendations from this research are to direct a standardization of temulawak extract and to conduct an effectiveness test of ethanol-temulawak extract against biofilm, using non-colorimetric methods (the extract's strong color affects measurements of optical density). Further investigation is also needed into the biomolecular aspects of temulawak resistance in A. actinomycetemcomitans.

\section{REFERENCES}

1. The Ministry of Health. Indonesia Basic Health Research. Jakarta: The Ministry of Health Republic of Indonesia; 2013

2. Inna M, Atmania N, Prismasari S, Gigi FK, Mada UG. Potential use of Cinnamomum burmanii essential oil-based chewing gum as oral antibiofilm agent. J Dent Indones 2010;17(3):80-6.

3. Tahmourespour A, Kermanshahi RK, Salehi R, Pero NG. Biofilm formation potential of oral streptococci in related to some carbohydrate substrates. Afr J Microbiol Res 2010;4(11):1051-6.

4. Kim JE, Kim HE, Hwang JK, Lee HJ, Kwon HK, Kim BI. Antibacterial characteristics of Curcuma xanthorrhiza extract on Streptococcus mutans biofilm. J Microbiol 2008;46(2):228-32.

5. Kouidhi B, Al Qurashi YM, Chaieb K. Drug resistance of bacterial dental biofilm and the potential use of natural compounds as alternative for prevention and treatment. Microb Pathog 2015;80:39-49.

6. Indonesian Food and Drugs Administration. InfoPOM-gerakan nasional minum temulawak 2005;6(6):1-4

7. Fidinina N. Efek Ekstrak Etanol Terhadap Viabilitas Streptococcus sanguinis Berdasarkan Uji Crystal Violet (in vitro). Thesis. Jakarta: Univesitas Indonesia; 2011.

8. Hertiani T, Pratiwi S. Effect of indonesian medicinal plants essential oils on Streptococcus mutans biofilm. Majalah Farmasi Indones 2011;22(3):174-81

9. Solmaz G, Korachi M. Inhibition and disruption properties of chlorhexidine gluconate on single and multispecies oral biofilms. Jundishapur J Microbiol 2013;6(1):61-6.

10. Mangunwardoyo W, Usia T. Antimicrobial and identification of active compound Curcuma xanthorrhiza roxb. Int J Eng Sci 2012;12(1):69-78.

11. Wen ZT, Yates D, Ahn SJ, Burne RA. Biofilm formation and virulence expression by Streptococcus mutans are altered when grown in dualspecies model. BMC Microbiol 2010;10:111.

12. Fredricks DN. The Human Microbiota: How Microbial Communities Affect Health and Disease. New York: John Wiley \& Sons; 2013.

13. Jakubovics NS, Palmer RJ. Oral Microbial Ecology: Current Research and New Perspectives. USA: Caister Academic Press; 2013.

14. Periasamy S,KolenbranderPE.Aggregatibacteractinomycetemcomitans builds mutualistic biofilm communities with Fusobacterium nucleatum and Veillonella species in saliva. Infect Immun 2009;77(9):3542-1. 